Barczi Attila - Harrach Tamás - Nagy Valéria

\title{
„A gazdálkodó legjobb munkatársa a földigiliszta"- avagy a minimális talajbolygatás jótékony hatása a talajszerkezetre
}

Attila Barczi - Tamás Harrach - Valéria Nagy: "The earthworm is the best workmate of the farmer"- or beneficial effect of minimal soil disturbance on soil structure

Abstract

In recent decades in Germany the soil structure is greatly improved on a substantial part of the arable land. Soil erosion can be observed less commonly. Since the 1970s in Germany the intensity of soil disturbance is significantly reduced. The less disturbed soil has more mechanical load, namely the stability. The perforated structure with stable biopores ensures ecological functions, such as infiltration, aeration, root permeability, fertility. For this reason, soil compaction and soil erosion occur less frequently, they can be detected only in exceptional cases. But in Hungary, the same can not be said therefore it is a desirable objective to explore the cause of differences. Usually the best soil structure can be found on the arable lands without rotation cultivated. In Germany we could study the condition of soils in farms which using no-till system. We have analyzed the effect of soil cultivation methods on the soil structure.

Keywords: soil structure, tillage methods, compaction, earthworm

\section{ÖSSZEFOGLALÓ}

Németországban az utóbbi évtizedekben a szántóföldek nagy részén jelentősen javult a talajszerkezet. Ritkábban figyelhető meg talajerózió. Az 1970-es évek óta Németországban szignifikánsan csökkent a talajok bolygatása a szántóföldi múvelés során. A kevésbé bolygatott talajnak nagyobb a mechanikai terhelhetősége, azaz a stabilitása. A mélybenyúló stabil biopórusokkal perforált szerkezet pedig biztosítja az ökológiai funkciókat, úgymint a megfelelő infiltrációt, a levegőztetést, a gyökérjárhatóságot és a termőképességet. Ennek okán a talajtömörödés ritkábban fordul elő és talajerózió is csak rendkívüli esetekben észlelhető. Ugyanez Magyarországon nem mondható el, ezért a különbségek okának felderítése kívánatos célkitúzésnek bizonyult. Legjobb talajszerkezet általában konzekvensen forgatás nélkül múvelt szántóterületeken található. Németországi tanulmányutunkon tanulmányozhattuk a talajok állapotát a forgatás nélküli talajmúvelési módot alkalmazó gazdaságokban. Vizsgáltuk a talajmúvelő eszközök talajszerkezetre gyakorolt hatását is.

Kulcsszavak: Talajszerkezet, múvelési módok, tömörödés, földigiliszta

\section{BEVEZETÉS}

Az 1970-es évek óta Németországban - részben racionalizációs céllal - jelentősen csökkent a talajbolygatás intenzitása, többnyire a forgatást is mellőzik.

A minimált talajmúvelésnek többféle változata is elterjedt, de alapvetően a vegyes talajmúvelési rendszerek dominálnak, ugyanis a termesztett növényekre kidolgozandó növényvédelmi stratégia jelentős befolyással bír a talajmúvelési rendszerre. A gazdaságok nagy része ugyan használ még ekét, de nem rendszeresen, és sekélyebb forgatást végeznek, mint korábban. Csak bizonyos növények előtt szántanak növényvédelmi célból, a vetésforgó 
többi tagja előtt pedig kultivátoroznak. Egyre inkább növekszik azoknak a gazdaságoknak a száma, amelyek alapozó múvelést kultivátorral végeznek és ekét egyáltalán nem használnak.

A talajbolygatás csökkentésével lényegesen javult a talajszerkezet, a tapasztalatok kielégítőek, a talajok állapotának javulása talajfizikai és terepi vizsgálati módszerekkel is igazolható. A talajszerkezet javulása összefüggést mutat a talajok biológiai aktivitásának fokozódásával. A forgatás nélküli talajmúvelés ugyanis kedvező életfeltételeket biztosít a földigilisztáknak (Lumbricus terrestris), hiszen szerves maradvány (mulcs) formájában elegendő táplálékhoz jutnak a felszínen. Ennek eredményeként tevékenységük javítja a talajszerkezetet. A fenntartható talajhasználat elősegítése/megteremtése érdekében feltétlenül indokolt a német talajmúvelési eljárásoknak és a talajok állapotának összefüggés-vizsgálata, majd a tapasztalatok megosztásával hozzá lehet járulni a minimális talajbolygatás hazai adaptálásához. Mi sem igazolja ezt jobban, mint Heisenberg szavai, miszerint „A tudomány két mozzanatból tevődik össze: a jelenségek megfigyeléséből és az eredmények másokkal való közléséből..." [Heisenberg 1978]. E célkitűzés megvalósítását vállaltuk fel egy németországi tanulmányút tervezésénél.

\section{A TALAJTÖMÖRÖDÉS KIALAKULÁSA ÉS MEGHATÁROZÁSA}

A termőföld védelméről szóló 2007. évi CXXIX. törvény értelmében a mezőgazdasági célú földterületek termőképességének fenntartása közös feladatunk, amelynek érdekében a földhasználónak a talaj tömörödésének megelőzésével vagy megszüntetésével meg kell akadályozni a káros vízbőség vagy belvíz kialakulását. A talaj ugyanis feltételesen megújuló természeti erőforrás, amely egyben a mezőgazdasági termelés és erdőgazdálkodás alapvető termelőeszköze. Ilyen módon a talajvédelem elsősorban minőségi védelmet jelent: a minőség megóvása, javítása, de mindenekelőtt a fizikai, kémiai és biológiai romlás megelőzése.
A német eredetű Packungsdichte fogalom azt a komplex, de egyszerű terepi módszert takarja, amely elsősorban a talajszerkezet állapotának értékelésére irányul. A terepi módszer elsődlegesen a talaj lazaságát/tömődöttségét vizsgálja, amely alapvetően befolyásolja a talaj legfontosabb tulajdonságait, mint a póruseloszlás, vízáteresztő képesség, levegőgazdálkodás, gyökerezhetőség és termékenység [DIN 19682-10].

A talaj tömődöttsége tulajdonképpen a talajrészecskék közötti adhéziós és kohéziós erők viszonyait tükrözi, ami a talaj megmunkálással szemben tanúsított ellenállásában jut kifejezésre. A tömődöttség igen sok tényezőtől függ: befolyásolják a talaj morfológiai, fizikai és kémiai tulajdonságai, de a talajt borító növényzet, a talajhasználat módja és az alkalmazott talajmúvelés is. A talajtömörödés meghatározásánál kiemelt szerepe van a talajnedvességnek.

A talaj tömődöttségét tekintve terepi viszonyok között az alábbi kategóriák különíthetőek el: omlós talaj, laza talaj, enyhén tömődött talaj, tömődött talaj, erősen tömődött talaj, igen erősen tömődött talaj, tömör talaj.

A talajszerkezet helyszíni vizuális megítélésében az egyszerű és mindenkor alkalmazható „Spatendiagnose” (,ásópróba”) módszer segíthet, valamint a folyamatos talajmintavételezés, növényvizsgálat és nem utolsósorban a terméshozam együttes összefüggés vizsgálata szolgáltat megbízható és a gyakorlatban hasznosítható eredményeket [Tebrügge et al. 1992]. A terepi talajvizsgálat tulajdonképpen az elméleti talajtani és talajmúvelési kutatások metszéspontjaként értelmezhető.

$\mathrm{Az}$ ásópróba ténylegesen a növény termőhelyének vizsgálatát jelenti, amely során a talaj szerkezetét, színét, a gyökéreloszlást, a talajban lévő pórusokat és az átmeneti szinteket vizsgáljuk. Maga a módszer elnevezése és leírása Görbingtől származik [Görbing 1947]. Ásópróbával a felszíntől kb. 25$28 \mathrm{~cm}$ mélységig vizsgálható a talaj szerkezete, nyirkossága, a tömör réteg helye, megítélhető a talaj állapota, beleértve a tömörséget, a talaj 
Barczi Attila - Harrach Tamás - Nagy Valéria: „A gazdálkodó legjobb munkatársa a földigiliszta” ...

nedvességét, és ennek megfelelően a múvelésre való alkalmasságot [Birkás 2007; Birkás 2010]. Gilisztajáratokat, gilisztákat általában egy ásónyomnyi mélységben is lehet találni. Kritikus esetben két ásónyomnyi mélységig érdemes a próbát elvégezni. A módszer előnye abban rejlik, hogy a terepen információt kaphatunk a talaj állapotáról. Mivel a vizsgálat során kisebb "talajszelvényt” készítünk, abból a gyökéreloszlást, a makropórusok arányát is kiválóan meg tudjuk határozni. A problémát csak az jelentheti, ha a talaj túlságosan nedves, vagy túlságosan ki van száradva. Éppen ezért a felvételezés időpontját célszerű általában a tavaszi időszakra tenni, amikor a talaj nedvességgel kedvezően átitatott. $A z$ ásópróba egyben jó kiegészítő vizsgálata lehet a talajtömörödésnek.

A fenntartható talajmúvelés és a talajszerkezet terepi vizsgálata témakörben az idei esztendő nyarán lehetőség nyílt ellátogatni a németországi Giessen-i székhelyú Justus-Liebig Egyetemre, az ország egyik legjelentősebb agrártudományi, talajtani és talajvédelmi tudományterületeken tevékenykedó felsőoktatási intézményébe (Justus-LiebigUniversität, Institut für Bodenkunde und Bodenerhaltung), amelynek jellegzetessége az interdiszciplinaritás. A szakmai tanulmányút megvalósítását a B2/4H/12385 regisztrációs számon nyilvántartott Campus Hungary Ösztöndíj támogatta. Bepillantást nyerhettünk és megismerhettük a fejlett gazdaságú Németország oktatási, kutatási struktúráját. A jelentős innovációnak köszönhetően a hazai infrastrukturális feltételekhez képest fejlettebb oktatási/kutatási technikával ismerkedhettünk meg a Justus-Liebig Egyetemen, ahol PhD képzés keretében kisebb, gyakorlati problémamegoldásokra irányuló témakutatásokat is végeznek. Ezek valós problémák megoldására irányulnak és az eredmények azonnal hasznosulnak az agrár- és környezetiparban. Az egyetem kutatási egységeiben egy adott területen azonos témában tevékenykedő, de különböző országokból érkező doktoranduszok és vendégprofesszorok dolgoznak együtt, ilyen módon kialakult az a nemzetközi színtér, ahol lehetővé válik a kutatási, oktatási és szakmai tapasztalatok megosztása. Elsősorban elméleti kutatásokat végeznek fejlett laboratóriumi háttérre támaszkodva. Azonban a gyakorlati ismeretek fontosságát hangsúlyozó és annak széleskörú elterjedéséhez bemutatóközpontok, gyakorlóközpontok létrehozására is szükség volt a németországi főiskolákon és egyetemeken. Ennek tökéletes példája látható a Triesdorf-i Hochschule Weihenstephan - University of Applied Sciences intézményben.

A helyi adottságokhoz, körülményekhez és igényekhez igazodó mezőgazdálkodás területén jelentős eredményeket tapasztaltunk, amelyhez hozzájárult az is, hogy az említett két felsőoktatási intézmény napjainkra nagyon erős kapcsolatokat hozott létre a gazdálkodókkal mind az alkalmazott kutatás, kísérleti fejlesztés, mind pedig az oktatás területén. Felismerték, hogy a bonyolultabb alkalmazott agrár jellegú kutatási feladatok megoldásának minden esetben a gazdálkodókkal együtt kell történnie, hiszen a felfedező és alkalmazott kutatások metszéspontja adja meg a problémákra a helyes választ. Ilyen módon az oktatás és kutatás (elmélet és gyakorlat) kapcsolódási pontjai messzemenően kielégítőek. Továbbá nagy hangsúlyt helyeznek az innovációra és az interdiszciplinaritásra. A Triesdorf-i Hochschule rendszeresen indít német nyelvű $M B A$ képzéseket a mezőgazdálkodás területén, amelynek lényege, hogy a farmokon végzett gyakorlati munka és az elmélet magas szintű elsajátítása ötvöződik. A képzésben résztvevők napjaink nemzetközi színtéren is ismert és elismert oklevelet és tudást szerezhetnek, hiszen a képzés mögött komoly nemzetközi szintű akkreditáció húzódik. A fentiek alapján az oktatói, kutatói és hallgatói bázisra épülve több gépgyártó és gépkereskedó is biztosít gyakorlati körülményeket megvalósító gyakorlótereket az oktatói/kutatói tevékenység kiváló színvonalú végzéséhez.

\section{A TALAJBOLYGATÁS HATÁSA A TALAJSZERKEZETRE - NÉMETORSZÁGI TAPASZTALATOK}




\begin{abstract}
A Justus-Liebig Egyetem Talajtani és tápanyagtartalma mellett a talajszerkezet is Talajvédelmi Intézetének munkatársai korlátozó tényező lehet [Tebrügge et al. 1992; elkötelezettek a természeti erőforrások - Beste 2002].

közöttük a talaj-fenntartható használata iránt, A Packungsdichte egyes fokozatai a talaj és már évekkel, sőt évtizedekkel ezelőtt tömődöttségét/lazaságát határozzák meg, ami felismerték, hogy ehhez a gazdálkodókkal számos igen fontos talajállapot jelzót foglal történő élő kapcsolattartás elengedhetetlenül magában, úgymint az összporozitást, a fontos.

Az Intézet kutatóinak szervezésében és Prof. Dr. Harrach Tamás vezetésével tanulmányozhattuk a német talajok állapotát a talajmúvelési módok és a talajmúvelő eszközök talajra gyakorolt hatásának feltárása céljából. Fontos alapelv, hogy a talaj és talajmúvelő eszközök között kialakuló interaktív kapcsolat ismérveit föleg terepi körülmények között lehet és kell tanulmányozni és vizsgálni a talajbiológiai folyamatok figyelembevételével, hiszen növények gyökerező, a talaj vízbefogadó és vízáteresztő képességét. A tanulmányút alkalmával az 1. ábrán feltüntetett német és bajor gazdaságokban (alapvetően a Giessen-i medencében és a Vorderer Vogelsberg kistájban) megismerkedhettünk az alkalmazott talajmúvelési eljárásokkal, módszerekkel, valamint a múvelt területek talajainak állapotával. Ezáltal adott volt a kutatók és a helyi gazdálkodók közötti közvetlen tapasztalatcsere is.
\end{abstract} növénytermesztés szempontjából a talaj

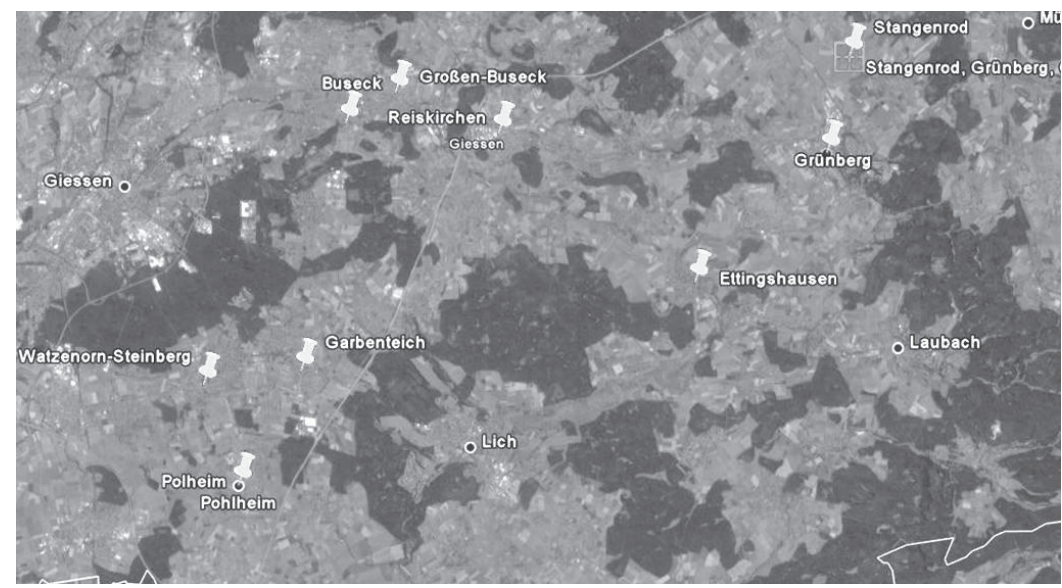

1. ábra Gießen-i medence, Grünberg és környéke, Vorderer Vogelsberg (Google Earth)

A gazdálkodók aktív közremúködésével 6 farm, illetve családi gazdaság működésébe is betekintést nyerhettünk, illetve a birtokterületeiken talajfeltárásokat, talajdiagnosztikai vizsgálatokat végezhettünk a német kollégákkal az 1 . táblázatban felsorolt gazdaságokban

A szakmai tanulmányút keretében meglátogatott gazdaságok elsődleges kiválasztási szempontja az volt, hogy többségük szántás/eke nélküli talajmúvelést (növénytermesztést) végezzen.
E talajmúvelés egyik oka, hogy szántóföldjeik részben sekély termőrétegúek, hiszen a Vogelsberg hegység bazaltján alakultak ki. A talajok emiatt jelentős mennyiségben kemény bazaltot, kőtörmeléket tartalmaznak. Azonban mind a sekély, rosszabb adottságú bazaltos talajokon, mind a termékenyebb löszvidékeken más szempont is érvényesül: a gazdálkodók az ökonómia mellett a talaj termőképességét nem csökkentő, hanem inkább növelő használatát tartják szem előtt. Mindkét ok motiváció és kihívás is egyben a gazdák számára. 
Barczi Attila - Harrach Tamás - Nagy Valéria: „A gazdálkodó legjobb munkatársa a földigiliszta” ...

\begin{tabular}{|c|c|c|c|c|}
\hline $\begin{array}{l}\text { gazdaság/ } \\
\text { gazdálkodó } \\
\text { elhelyezkedés }\end{array}$ & $\begin{array}{c}\text { táj, } \\
\text { évi közép- } \\
\text { hőmérséklet/ } \\
\text { átlagos évi } \\
\text { csapadék }\end{array}$ & $\begin{array}{l}\text { múvelt terület } \\
\text { nagysága } \\
\text { (termesztett } \\
\text { növények) }\end{array}$ & $\begin{array}{l}\text { föbb talajtípusok } \\
\text { (talajok pontértéke } \\
\text { a } 100 \text { pontos } \\
\text { rendszerben) }\end{array}$ & talajmúvelés \\
\hline $\begin{array}{l}\text { Peter Fay } \\
\text { Pohlheim, } \\
\text { Watzenorn- } \\
\text { Steinberg }\end{array}$ & $\begin{array}{l}\text { Giesseni medence } \\
8,9^{\circ} \mathrm{C} / 600 \mathrm{~mm}\end{array}$ & $\begin{array}{l}120 \text { ha } \\
\text { (vetésforgóban } \\
\text { repce, őszi búza, } \\
\text { rozs, tavaszi árpa) }\end{array}$ & $\begin{array}{lr}\text { részben } & \text { sekély } \\
\text { termőrétegű } & \text { köves, } \\
\text { illetve } & \text { agyagos } \\
\text { talajok } & \text { bazaltból } \\
\text { (30-35), részben } \\
\text { kitűnő } & \text { lösztalajok } \\
\text { (70-84) } & \\
\end{array}$ & $\begin{array}{l}\text { kultivátorral - } \\
10 \text { év óta } \\
\text { részben, } 5 \text { év óta } \\
\text { teljesen szántás } \\
\text { nélkül }\end{array}$ \\
\hline $\begin{array}{l}\text { Agrarservice Bank } \\
\text { GmbH } \\
\text { Oliver Jung } \\
\text { Reiskirchen, } \\
\text { Ettingshausen }\end{array}$ & $\begin{array}{l}\text { Vorderer, } \\
\text { Vogelsberg } \\
8,0-9,0{ }^{\circ} \mathrm{C} / 600- \\
750 \mathrm{~mm}\end{array}$ & $\begin{array}{l}700 \text { ha } \\
\text { (vetésforgóban } \\
\text { repce, őszi búza, } \\
\text { tavaszi árpa, tavaszi } \\
\text { árpa) }\end{array}$ & $\begin{array}{lr}\begin{array}{l}\text { részben } \\
\text { termőrétegű }\end{array} & \text { sekély } \\
\text { illetve } & \text { köves, } \\
\text { talajok } & \text { bazagos } \\
\text { (30-35), rél } & \text { részben } \\
\text { kilúgozott } & \\
\text { lösztalajok } & (55-68), \\
\text { részben } & \text { kiváló } \\
\text { lösztalajok } & (68-74)\end{array}$ & $\begin{array}{l}\text { kultivátorral - a } \\
\text { terület egy } \\
\text { részén több mint } \\
20 \text { év óta teljesen } \\
\text { szántás nélkül }\end{array}$ \\
\hline $\begin{array}{ll}\text { Dr. } & \text { Dietmar } \\
\text { Schmidt } & \\
\text { Buseck, } & \text { Großen- } \\
\text { Buseck } & \end{array}$ & $\begin{array}{l}\text { Giesseni medence } \\
8,8{ }^{\circ} \mathrm{C} / 600-650 \\
\mathrm{~mm}\end{array}$ & $\begin{array}{l}165 \\
\text { (vetésforgóban } \\
\text { repce, őszi búza, őszi } \\
\text { vagy tavaszi búza, } \\
\text { őszi árpa) }\end{array}$ & $\begin{array}{lr}\text { részben } & \text { sekély } \\
\text { termőrétegú } & \text { köves, } \\
\text { illetve } & \text { agyagos } \\
\text { talajok } & \text { bazaltból } \\
(45-65), & \text { nagyrészt } \\
\text { kiváló } & \text { lösztalajok } \\
(68-75) & \\
\end{array}$ & $\begin{array}{l}\text { kultivátorral, } \\
\text { szántás nélkül }\end{array}$ \\
\hline $\begin{array}{l}\text { Manfred Balser } \\
\text { Pohlheim, } \\
\text { Garbenteich }\end{array}$ & $\begin{array}{l}\text { Giesseni medence } \\
8,8^{\circ} \mathrm{C} / 600 \mathrm{~mm}\end{array}$ & $\begin{array}{l}70 \text { ha } \\
\text { (vetésforgóban } \\
\text { repce, őszi búza, } \\
\text { rozs, tavaszi árpa, } \\
\text { őszi árpa) }\end{array}$ & $\begin{array}{lr}\text { részben sekély } \\
\text { termőrétegú } \\
\text { illetve köves, } \\
\text { talajok bagyagos } \\
\text { (36-55), részben } \\
\text { pszeudoglejes } \\
\text { lösztalajok (55-70) }\end{array}$ & $\begin{array}{l}\text { kultivátorral, } \\
\text { néha sekélyen } \\
\text { tárcsával - } 10 \text { év } \\
\text { óta részben, } 5 \text { év } \\
\text { óta teljesen } \\
\text { szántás nélkül }\end{array}$ \\
\hline $\begin{array}{l}\text { Reinhard Keil } \\
\text { Reiskirchen, } \\
\text { Ettingshausen }\end{array}$ & $\begin{array}{l}\text { Vorderer, } \\
\text { Vogelsberg } \\
8,5^{\circ} \mathrm{C} / 600-650 \\
\mathrm{~mm}\end{array}$ & $\begin{array}{l}260 \text { ha } \\
\text { (vetésforgóban } \\
\text { repce, őszi búza, } \\
\text { tavaszi árpa) }\end{array}$ & $\begin{array}{lr}\text { részben } & \text { sekély } \\
\text { termőrétegú } & \text { köves, } \\
\text { illetve agyagos } \\
\text { talajok bazaltból } \\
\text { (38-55), részben } \\
\text { kilúgozott } \\
\text { lösztalajok (55-68) }\end{array}$ & $\begin{array}{l}\text { hagyományos } \\
\text { talajmúvelés } \\
\text { szántással, de } \\
\text { esetenként } \\
\text { kultivátorral } \\
\text { szántás nélkül }\end{array}$ \\
\hline $\begin{array}{l}\text { Henning Schäfer } \\
\text { Grünberg, } \\
\text { Stangenrod }\end{array}$ & $\begin{array}{l}\text { Vorderer, } \\
\text { Vogelsberg } \\
8,1^{\circ} \mathrm{C} / 750 \mathrm{~mm}\end{array}$ & $\begin{array}{l}190 \text { ha } \\
\text { (vetésforgóban } \\
\text { repce, őszi búza, őszi } \\
\text { árpa, tavaszi árpa) }\end{array}$ & $\begin{array}{l}\text { részben sekély } \\
\text { termőrétegű köves } \\
\text { talajok bazaltból } \\
(38-55), \quad \text { részben } \\
\text { kilúgozott } \\
\text { lösztalajok (55-74) }\end{array}$ & $\begin{array}{l}\text { kultivátorral - } 12 \\
\text { év óta részben } \\
\text { szántás nélkül, } 4 \\
\text { év óta többnyire } \\
\text { szántás nélkül }\end{array}$ \\
\hline
\end{tabular}

1. táblázat Gazdaságok főbb adatai 
A fentiek értelmében Németországban a minimális talajbolygatást eredményezó talajmúvelés igen elterjedt. A talajmúvelés minőségét az alapján is értékelik, hogy milyen mértékben sikerül a talajbiológiai folyamatokat figyelembe venni. A német mezőgazdasági gépipar, többek között az élenjáró Horsch cég, ezt belátta és abszolút partnerségével elősegítette a körülményekhez és igényekhez alkalmazkodó talajmúvelés elterjedését (a hozzá kapcsolódó géppark folyamatos fejlesztésével). A meglátogatott gazdaságokban a talajmúvelés részben közös gépvásárlás és géphasználat keretében zajlik, amelynek alapja a megmúvelendő földterületek tulajdoni hányada.

A minimális talajbolygatásnak köszönhetően a talajszerkezet Németországban a szántóföldek jó részén nagyon jó állapotban van, legalábbis lényegesen jobb, mint 30-40 évvel ezelőtt. Ugyanez Magyarországon nem mondható el annak ellenére, hogy a 2010-ben közzétett Nemzeti Együttmúködés Programjában foglaltak szerint a kormánycélok között helyet kapott a talajvédelem: "Olyan sokrétú mezőgazdaság, környezet- és tájgazdálkodás megteremtése a cél, amely úgy állít elő értékes, a természetet a lehetö legkevésbé terhelö, egészséges és biztonságos élelmiszereket, valamint helyi energiákat és különféle nyersanyagokat, hogy közben megörzi talajainkat, ivóvízkészleteinket, az élővilágot, természeti értékeinket." [NEP 2010] Ezért a különbségek okának felderítése kívánatos célkitǔzésnek bizonyul, hiszen a németországi jó gyakorlatok adaptálásával a talajszerkezetet Magyarországon is javítani lehetne. Az alapvetó különbség a talajbolygatás intenzitása. Minél kevesebbet bolygatjuk a talajt, annál jobb a talajszerkezet, mert egyrészt a túlzott múvelés a talajszerkezet szétesésével jár együtt, másrészt a kevés bolygatás - elősegítve a talajbiológiai folyamatokat és a földigiliszták elszaporodását - a kiváló, stabil szerkezet kialakulásában kulcsszerepet tölt be.

A Németországban elterjedt minimális talajbolygatás tapasztalatai jók, dokumentált eredményeket értek el. Különösen kedvező a talajszerkezet ott, ahol évek - sőt évtizedek óta nem szántottak. A szántás legnagyobb hátránya ugyanis - a nagy energiaigény és munkaóra mellett - a mélyebb forgatás. A szerves maradvány a mélybe (akár 20-40 cm) kerül és nem marad mulcs a felszínen, ezért a talaj pórusviszonyait javító és a talajszerkezet felépítésében kulcsszerepet játszó földigiliszták (Lumbricus terrestris) nem jutnak elegendő szervesanyagban gazdag táplálékhoz a felszínen. Szántás nélkül viszont a felszínen maradó mulcs biztosítja a földigiliszták életfeltételeit. (Itt megjegyzendő, hogy a mulcs egyenletes szétterítése nem igényel többletkapacitást, mert a gabonabetakarítással egy menetben történik.) Tehát minél kevesebb a talajbolygatás és minél több a mulcs, annál több földigiliszta van, és tevékenységük jobb talajszerkezetet eredményez. A növényi maradványok, mint táplálék mellett fontos a talajok mésztartalma, mészmentes talajokon ezért rendszeresen meszezni kell, máskülönben a biológiai folyamatok romlanak, amely kedvezőtlenül hat a földigiliszták aktivitására.

Természetesen nem szabad elhanyagolni azt a szempontot sem, hogy a talajmúvelési eljárásoknak más feladata is van. A szántás és a mélyebb tárcsázás növényvédelmi célokat (is) szolgál. A minimális talajbolygatás alkalmazói ezért vegyszerkijuttatással ellensúlyozzák a termesztett kultúrnövények elgyomosodását, illetve növényvédelmét. A forgatás nélküli talajművelés bevezetésekor tehát a megfelelő növényvédelmi stratégia kidolgozása jelenti a legnagyobb kihívást. Erre a vegyszerhasználat kínálkozik lehetőségként, de vannak más megoldások is. Ezt igazolják azok a biogazdaságok, amelyek növekvő számban térnek át forgatásmentes, minimális talajbolygatással járó múvelésre.

A talajszerkezetet terepen az ásópróbával vizsgáltuk. A meglátogatott gazdaságok szántóterületein sehol nem tapasztaltunk „káros tömörödést”. Az egykor szántott feltalaj 18-25 cm mélyen kultivátorozott része kimondottan laza és morzsás szerkezetű, ami az alatta fekvő rétegekben már nem áll fenn. $\mathrm{A}$ 
Barczi Attila - Harrach Tamás - Nagy Valéria: „A gazdálkodó legjobb munkatársa a földigiliszta” ...

korábbi években mintegy 32-35 cm mélyen szántottak. Az évek óta nem bolygatott feltalaj körülbelül 25-35 cm mélységében már nehezebben ásható, és első benyomásra tömörödöttnek túnik, viszont közelebbről megtekintve megállapítható, hogy ezt az aránylag tömör szintet is sok biopórus járja át, főleg gyökércsatorna és gilisztajárat.

A 2. ábra egy ilyen, több éve forgatás nélküli talaj szerkezetét mutatja, ahol a talajfelszín közelében laza, morzsás szerkezet látható, és a mélyebb rétegekben sincs káros tömörödés. $A$ nagyszámú függőleges biopórus biztosítja az infiltrációt, a légcserét és a gyökérfejlődést (3. ábra). A talaj ökológiai funkciói tehát sértetlenek, ilyen módon tehát a káros tömörödés kizárható. Ugyanakkor a tömörödöttebb mátrix nagy stabilitással rendelkezik és a talajmúvelő eszközök terhelésekor védi az altalajt is tömörödéstől. Ezért a megvizsgált talajokban az egykor szántott szint alatt az altalajban nincs nyoma a tömörödésnek. Itt különösen sok biopórus látható szabad szemmel (3. ábra). Ebben az állapotban ezt a réteget nem érdemes bolygatni, mert a fennálló mérsékelt tömörödés nagy hordképességet biztosít. A szint lazítása viszont megsemmisítené a jelenlevő kimondottan stabil biopórusokat.
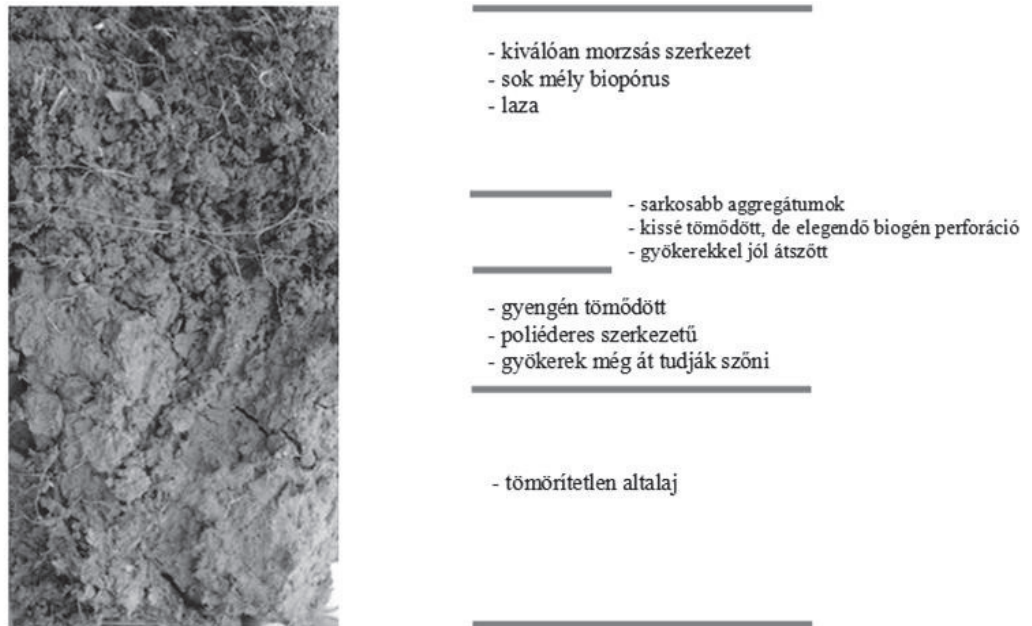

2. ábra Bolygatatlan talaj szerkezete

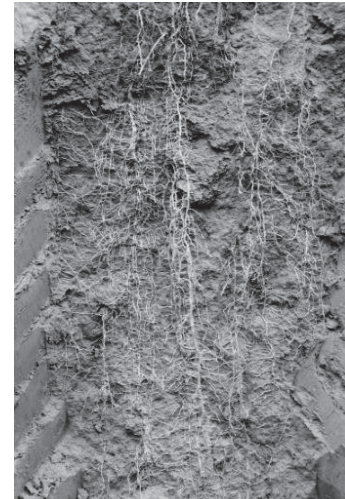

3. ábra Biopórusok és a pórusokat átszövő gyökérzet a bolygatatlan talajban
A korábban hivatkozott, egyszerú ásópróba módszerrel megállapítható és bizonyítható a csökkentett talajbolygatás pozitív hatása a talaj szerkezetére az egész szelvényben. A mulcshagyás következtében elszaporodik a földigiliszta és javítja a talajszerkezetet és a porozitást. Ilyen gazdálkodás esetén alig fordul elő múvelés által okozott talajtömörödés és pangó víz, nem cserepesedik a talajfelszín és csak nagyon ritkán fordul elő talajerózió.

Amennyiben a növényvédelmi stratégia is sikeres, megfelelően fejlődnek a növényegyedek, amelyek még a tábla erősebbe taposott fordulójában vagy a múvelési utakban 
sem mutatnak a talajszerkezetre visszavezethető hiányosságot.

Tehát a rossz talajszerkezet, káros tömörödés a talajfelszín cserepesedésén, pangó vízen, talajeróziós jelenségeken és nem utolsó sorban a növényállomány szuboptimális (hiányos) fejlődésén ismerhető fel. Különösen extrém időjárás esetén még inkább figyelni kell ezekre a jelekre. Ásópróbával egyszerúen megállapítható, hogy melyik talajszintben káros a tömörödés. Különös figyelmet igényel, ahol hiányoznak a biopórusok (gyökércsatornák, gilisztajáratok). A károsan tömörödött szintet lazítani kell, mert erős tömörödés nem javítható csupán a biológiai folyamatok útján. Itt megjegyzendő azonban, hogy a lazított talaj stabilitása csekély, az újratömörödés veszélye nagy. Ezért csak indokolt esetben végezhető a beavatkozás, és csak olyan mélyen szabad a talajt bolygatni, amilyen mélyen ténylegesen szükséges. A lazítást csak megfelelö, „földnedves” állapotban szabad elvégezni.

Számos kísérlet és gyakorlati tapasztalat igazolja, hogy talajbolygatás nélkül direktvetéssel is maximális termés érhető el, ha megfelelő vetéstechnikát és növényvédelmi stratégiát alkalmaznak. Talajlazításra csak akkor van szükség, ha a talajszerkezet károsodott.

A gazdák a talaj állapotának meghatározása céljából a mezőgazdasági munkálatokhoz igazodóan évente kb. 3-4 terepi felmérést végeznek/végeztetnek (talajtani szakértő, terepi talajtani szakértő). E munkálatok elvégzése elemi érdekük, hiszen az "adózási” rendszerük alapvetően a talajok állapotának megőrzésén, illetve javításán alapszik (a talajértékelés az ún. 100 pontos talajosztályozási rendszerben történik).

A tanulmányút keretében meglátogatott németországi gazdaságok példáján keresztül tökéletesen körvonalazódott, hogy az alkalmazkodó mezőgazdálkodás interdiszciplináris (agrár, agrárműszaki, növényvédelmi) jellege napjainkban egyre fontosabbá válik, továbbá az alapkutatás mellett nélkülözhetetlenek a gyakorlati tapasztalatok is, így a regionális mezőgazdasági kutató intézményekkel és a regionális gazdaságokkal karöltve látványos eredmények érhetők el.

\section{3. ÖSSZEGZÉS}

Örömünkre szolgált, hogy a fenntartható és alkalmazkodó mezőgazdálkodás lehetőségeit és kihívásait német kollégáinkkal és a helyi gazdálkodókkal együtt hasonlóan látjuk, így kutatómunkánk célkitúzése is azonos: a talajok állapotának javítása, amely kutatás sosem lehet öncélú, mindenkor a társadalmi kihívásokra adandó válaszok kidolgozásának a szolgálatában kell állnia, azonosulva a "Messze látó tudomány: felelős válaszok a jövőnek." mottó mondanivalójával.

Abban mindannyian egyetértünk, hogy a természeti környezet hozzájárul az emberi jólléthez. Németországban is sokat vitatott kérdés, hogy milyen mélyen kell a talajt múvelni, hiszen a szántás és a vele járó sok kapcsolt munkamúvelet többek között energiaigényes is. Ezért fokozódik az igény az ökonómiailag gazdaságosabb, kevesebb múvelettel járó megoldások iránt. Egyetemes válasz azonban nincs a stratégiára, a helyi és egyedi adottságok, valamint tapasztalatok alapján kell a megfelelő talajművelési stratégiát kidolgozni, amelynek során több szempontot is kell figyelembe venni, mégpedig:

- Szántás nélküli múvelés esetén elszaporodnak a giliszták és javítják a talajszerkezetet.

- Különös jelentőséggel bírnak a függőlegesen mélybe nyúló és a talajfelszínen nyílt gilisztajáratok. Minél nagyobb ezeknek a száma négyzetméterenként, annál kedvezőbbek az infiltráció lehetőségei, tehát annál jobb a talaj víznyelő képessége.

- Az altalaj bolygatása csak akkor indokolt, ha a mélyebb szintben a tömörödést kell fellazítani.

- Az optimális talajszerkezet elérése céljából már betakarításkor gondoskodni kell a szalma aprításáról (lehetőleg $<4$ $\mathrm{cm})$ és egyenletes elterítéséről. Az új 
Barczi Attila - Harrach Tamás - Nagy Valéria: „A gazdálkodó legjobb munkatársa a földigiliszta” ...

vetéstechnikák lehetővé teszik a A minimális talajbolygatás hazai adaptálásához mulcshagyást, ami a talajvédelem és és az adottságaink ismeretében a lehetőségek talajbiológia szempontjából nagyon vizsgálatához csak az egész társadalomra értékes.

kiterjedő szemléletformáló, oktató,

- A növényvédelmi stratégiával szemben ismeretátadó tevékenységre és helyes alapokon támasztott követelmény a mérsékelt nyugvó oktató, kutatómunkán keresztül vegyszerfelhasználás, illetve az ökológiai vezethet az út. A tanulmányút keretében tett eljárások alkalmazásának előtérbe látogatás teljes mértékben alátámasztotta ezt a helyezése. lehetséges utat.

\section{IRODALOMJEGYZÉK}

[1] Beste, A (2002): Weiterentwicklung und erprobung der spatendiagnose als feldmethode zur bestimmung ökologisch wichtiger gefügeeigenschaften landwirtschaftlich genutzter böden. Dissertation, Universität Gießen

[2] Birkás M. (szerk.) (2007): Földmúvelés és földhasználat. Mezőgazda Kiadó, Budapest

[3] Birkás M. (szerk.) (2010): Talajmúvelők zsebkönyve. Mezőgazda Kiadó, Budapest

[4] DIN 19682-10 (német szabvány)

[5] Görbing, J - Sekera, F (1947): Die Spatendiagnose - Ziel und Grundlage der zweckmäßigen Bodenbearbeitung. Hannover

[6] Heinsenberg, W (1978): A rész és az egész. Gondolat Kiadó, Budapest

[7] Nemzeti Együttmúködés Programja 2010

[8] Tebrügge, $\mathrm{F}$ et al. (1992): Die ökologischen und ökonomischen Aspekte von Bodenbearbeitungs systemen. In: Wechselwirkungen von Bodenbearbeitungssystemen auf das Ökosystem Boden. Beiträge zum 3. Symposium, Mai 1992 in Gießen, pp. 7-20

[9] 2007. évi CXXIX törvény a termőföld védelméről 